DOI: https://doi.org/10.47405/mjssh.v5i6.654

\begin{tabular}{|c|c|}
\hline 4 & Malaysian Journal of Social Sciences and Humanities (MJSSH) \\
\hline $\begin{array}{l}\text { Malaysian Juoural of } \\
\text { Social ccciecces and }\end{array}$ & Volume 5, Issue 6, June 2020 \\
\hline (MJ-sSH) & e-ISSN : 2504-8562 \\
\hline & $\begin{array}{l}\text { Journal home page: } \\
\text { www.msocialsciences.com }\end{array}$ \\
\hline
\end{tabular}

\title{
Aplikasi Kemahiran Belajar dan Inovasi (4C) dalam kalangan Murid Sejarah: Satu Tinjauan Awal
}

\author{
M. Kaviza ${ }^{1}$ \\ 1Pusat Pengajian Pendidikan dan Bahasa Moden, Universiti Utara Malaysia (UUM) \\ Correspondence: M. Kaviza (kavizakaviza@yahoo.com)
}

\begin{abstract}
Abstrak
Kajian secara deskriptif ini bertujuan untuk mengenal pasti tahap aplikasi kemahiran belajar dan inovasi (4Cs) iaitu kemahiran komunikasi, kemahiran pemikiran kritis, kemahiran kreativiti, kemahiran kolaborasi dalam kalangan murid. Seramai 60 orang murid tingkatan empat yang ditentukan berdasarkan teknik persampelan rawak mudah. Soal selidik merupakan instrumen kajian ini. Data kajian ini dianalisis secara deskriptif iaitu min dan sisihan piawai dan secara inferensi iaitu ujian-t sampel tak bersandar melalui perisian IBM SPSS. Dapatan kajian ini menunjukkan bahawa tahap aplikasi kemahiran belajar dan inovasi ( $4 C S$ ) iaitu kemahiran komunikasi, kemahiran pemikiran kritis, kemahiran kreativiti, kemahiran kolaborasi berada pada tahap sederhana tinggi dalam kalangan murid. Tambahan pula, dapatan kajian ini juga menunjukkan tahap aplikasi kemahiran belajar dan inovasi (4Cs) berada pada tahap sederhana tinggi dalam kalangan murid lelaki dan murid perempuan walaupun tidak terdapat perbezaan min yang signifikan bagi aplikasi kemahiran belajar dan inovasi (4Cs) berdasarkan jantina. Implikasi kajian ini menyediakan sumber maklumat kepada para guru untuk merancang dan melaksanakan proses pembelajaran sejarah dengan mengaplikasikan kemahiran belajar dan inovasi ( $4 C s)$ dengan lebih meluas lagi.
\end{abstract}

Kata kunci: Kemahiran belajar dan inovasi $(4 C s)$, mata pelajaran sejarah, murid

\section{The Application of the Learning and Innovation Skills (4Cs) among History Students: A Preliminary Study}

\begin{abstract}
The descriptive study aims to identify the level of application of the learning and innovation skills (4Cs), such as communication, critical thinking, creativity and collaboration skills among students. A total of 60 form four students are selected through simple random sampling techniques. The questionnaires are the instrument of this study. The data of this study were analysed descriptively, such as mean and standard deviation and inferentially, such as independent sample t-test using IBM SPSS software. The findings of this study indicated that the level of application learning and innovation skills (4Cs), such as communication, critical thinking, creativity and collaboration skills at moderately high level among students. In addition, the findings of this study have also shown that the level of application learning and innovation skills (4Cs) at moderately high level among male and female students, even though the finding in this study proved that there is no significant difference in the mean of application learning and innovation skills (4Cs) based gender. The implications of this study are provided information for teachers to plan and implement learning of history subject by applying learning and innovation skills (4Cs) widely.
\end{abstract}


Keywords: Learning and innovation skills (4Cs), history subject, students

\section{Pengenalan}

Oleh kerana kejayaan sesuatu sistem pendidikan adalah dinilai melalui tahap pembelajaran dan perkembangan murid, maka pihak Kementerian Pendidikan Malaysia (KPM) telah bertekad untuk meningkatkan kualiti kemenjadian murid berdasarkan pencapaian enam ciri aspirasi murid iaitu pengetahuan, kemahiran berfikir, kemahiran memimpin, kemahiran dwibahasa, etika dan kerohanian dan identiti nasional seperti yang disarankan dalam Pelan Pembangunan Pendidikan Malaysia 20132025 (KPM, 2013). Saranan terhadap peningkatan kualiti kemenjadian murid tersebut adalah berlandaskan kepada Falsafah Pendidikan Malaysia yang bermatlamat untuk memperkembangkan potensi individu secara menyeluruh dan bersepadu dalam melahirkan insan yang seimbang dan harmonis dari segi intelek, rohani, emosi dan jasmani berdasarkan kepercayaan dan kepatuhan kepada Tuhan, di samping untuk melahirkan rakyat Malaysia yang berilmu pengetahuan, berketerampilan, berakhlak mula, bertanggungjawab dan berkeupayaan mencapai kesejahteraan diri serta memberi sumbangan terhadap keharmonian dan kemakmuran keluarga, masyarakat dan negara (Pusat Perkembangan Kurikulum [PPK], 2018). Sehubungan dengan itu, untuk mencapai kualiti kemenjadian murid tersebut, maka salah satu hasrat dalam Kurikulum Standard Sekolah Rendah (KSSR) dan Kurikulum Standard Sekolah Menengah (KSSM) adalah bertujuan untuk melahirkan murid yang mempunyai kemahiran abad ke-21 yang berkualiti tinggi dengan memberikan fokus kepada kemahiran berfikir serta kemahiran hidup dan kerja yang berteraskan kepada amalan nilai murni agar mereka dapat bersaing pada peringkat global (PPK, 2018; Nurazuraini, Mahzan \& Abdul Razaq, 2016; Said Hamid, 2019).

Adalah tidak dapat disangkal bahawa kemahiran abad ke-21 mempunyai satu set standard kemahiran yang khusus yang perlu diterapkan secara menyeluruh dalam kalangan murid iaitu kemahiran belajar dan inovasi (Learning and Innovation Skills $-4 C s$ ), kemahiran hidup dan kerjaya (Life and Career Skills) dan kemahiran teknologi maklumat, komunikasi dan media (Information, Media and Technology Skills) melalui kandungan teras dan tema, kurikulum, standard dan pentaksiran, pembangunan profesional dan persekitaran pembelajaran (Patnership For 21 ${ }^{\text {st }}$ Century Skills, 2006). Sehubungan dengan itu, terdapat empat kemahiran belajar dan inovasi (4Cs) yang utama yang perlu difokuskan dalam aspek proses pembelajaran dalam kalangan murid iaitu:

i. Kemahiran komunikasi merujuk kepada proses pertukaran maklumat daripada murid kepada murid yang lain.

ii. Kemahiran pemikiran kritis merujuk kepada keupayaan murid untuk membuat penilaian mengenai sesuatu perkara.

iii. Kemahiran kreativiti merujuk kepada proses penghasilan sesuatu yang baharu, berguna dan berkualiti.

iv. Kemahiran kolaborasi merujuk kepada sesuatu perkara yang dilakukan secara berkumpulan.

Sungguhpun begitu, tahap aplikasi kemahiran belajar dan inovasi (4Cs) dalam kalangan murid sejarah masih belum diketahui lagi walaupun guru-guru pelatih sejarah telah dilaporkan mempunyai tahap kesediaan yang tinggi terhadap pelaksanaan pengajaran abad ke-21 dari aspek pengetahuan, kemahiran dan sikap (Muhammad Ayisy \& Mohd Ashraf, 2019) dan Model Bersepadu Penerapan Kemahiran Abad ke-21 dalam pengajaran dan pembelajaran sejarah telah mencadangkan kepada pengintegrasian kaedah pengajaran seperti pembelajaran koperatif, bijik darjah demokratik dan teknik motivasi bersesuaian (Rohani, Hazri \& Mohammad Zohir, 2017), di samping tahap sokongan guru dan penglibatan murid dalam aktiviti pembelajaran yang berada pada tahap sederhana tinggi (Irwan, Mohd Mahzan \& Abdul Razaq, 2019) dan tahap kemahiran terarah kendiri murid dari aspek pengurusan kendiri, keazaman untuk belajar dan kawalan kendiri terhadap proses pembelajaran sejarah yang berada pada tahap sederhana (Kaviza, 2020). Justeru, terdapat satu keperluan kepada pengkaji untuk meninjau tahap aplikasi kemahiran belajar dan inovasi (4Cs) iaitu kemahiran komunikasi, kemahiran 
DOI: https://doi.org/10.47405/mjssh.v5i6.654

pemikiran kritis, kemahiran kreativiti dan kemahiran kolaborasi dalam kalangan murid sejarah bagi membolehkan guru-guru mengambil langkah sewajarnya dalam penjanaan dan pengaplikasian kemahiran-kemahiran tersebut dalam proses pembelajaran dan pemudahcaraan mata pelajaran sejarah. Maka, tujuan kajian ini ialah untuk mengenal pasti tahap aplikasi kemahiran belajar dan inovasi (4Cs) iaitu kemahiran komunikasi, kemahiran pemikiran kritis, kemahiran kreativiti dan kemahiran kolaborasi dalam kalangan murid sejarah.

\section{Objektif Kajian}

Objektif kajian ini ialah:

i. Mengenal pasti tahap aplikasi kemahiran belajar dan inovasi (4Cs) iaitu kemahiran komunikasi, kemahiran pemikiran kritis, kemahiran kreativiti dan kemahiran kolaborasi.

ii. Mengenal pasti tahap aplikasi kemahiran belajar dan inovasi (4Cs) iaitu kemahiran komunikasi, kemahiran pemikiran kritis, kemahiran kreativiti dan kemahiran kolaborasi berdasarkan jantina.

iii. Mengenal pasti sama ada terdapat perbezaan min yang signifikan bagi aplikasi kemahiran belajar dan inovasi (4Cs) iaitu kemahiran komunikasi, kemahiran pemikiran kritis, kemahiran kreativiti dan kemahiran kolaborasi berdasarkan jantina.

\section{Soalan Kajian}

Soalan kajian ini ialah:

i. Apakah tahap aplikasi kemahiran belajar dan inovasi (4Cs) iaitu kemahiran komunikasi, kemahiran pemikiran kritis, kemahiran kreativiti dan kemahiran kolaborasi?

ii. Apakah tahap aplikasi kemahiran belajar dan inovasi (4Cs) iaitu kemahiran komunikasi, kemahiran pemikiran kritis, kemahiran kreativiti dan kemahiran kolaborasi berdasarkan jantina?

iii. Adakah terdapat perbezaan min yang signifikan bagi aplikasi kemahiran belajar dan inovasi (4Cs) iaitu kemahiran komunikasi, kemahiran pemikiran kritis, kemahiran kreativiti dan kemahiran kolaborasi berdasarkan jantina?

\section{HIPOTESI KAJIAN}

Bagi menjawab soalan kajian 3, maka hipotesis kajian berikut telah dibentuk iaitu:

$\mathrm{H}_{\mathrm{ol}}$ : Tidak terdapat perbezaan min yang signifikan bagi aplikasi kemahiran belajar dan inovasi (4Cs) berdasarkan jantina.

$\mathrm{H}_{\mathrm{ola}}$ : Tidak terdapat perbezaan min yang signifikan bagi aplikasi kemahiran komunikasi berdasarkan jantina.

$\mathrm{H}_{\text {olb: }}$ Tidak terdapat perbezaan min yang signifikan bagi aplikasi kemahiran pemikiran kritis berdasarkan jantina.

$\mathrm{H}_{\mathrm{olc}}$ : Tidak terdapat perbezaan min yang signifikan bagi aplikasi kemahiran kreativiti berdasarkan jantina.

$\mathrm{H}_{\mathrm{old}}$ : Tidak terdapat perbezaan min yang signifikan bagi aplikasi kemahiran kolaborasi berdasarkan jantina. 


\section{Metod Kajian}

Kajian berbentuk tinjauan dengan menggunakan soal selidik ini melibatkan seramai 60 orang murid Tingkatan Empat sebagai sampel kajian ini yang telah dipilih melalui teknik persampelan rawak mudah. Nilai Cronbach Alpha iaitu 0.85 bagi soal selidik telah menunjukkan bahawa instrumen tersebut mempunyai nilai kebolehpercayaan yang baik dan boleh diterima dalam kajian ini (Nunnally, 1978). Data kajian ini telah dianalisis secara statistik deskriptif iaitu min dan sisihan piawai dan statistik inferensi iaitu ujian-t sampel tak bersandar melalui perisian IBM SPSS. Interpretasi tahap aplikasi kemahiran belajar dan inovasi (4Cs) dalam kajian ini adalah seperti ditunjukkan pada Jadual 1 .

Jadual 1: Interpretasi Min dan Tahap

\begin{tabular}{ll}
\hline Skor Min & Tahap \\
\hline $4.01-5.00$ & Tinggi \\
$3.01-4.00$ & Sederhana Tinggi \\
$2.01-3.00$ & Sederhana Rendah \\
$1.00-2.00$ & Rendah \\
\hline
\end{tabular}

Sumber: Nunnally (1978)

\section{Dapatan Kajian}

\section{Tahap Aplikasi Kemahiran belajar dan inovasi (4Cs)}

Berdasarkan Jadual 2, tahap aplikasi kemahiran $4 C s(M=3.79, S D=0.19)$ berada pada tahap sederhana tinggi. Maka, dapat dirumuskan bahawa tahap aplikasi kemahiran belajar dan inovasi (4Cs) dalam kalangan murid sejarah berada pada tahap sederhana tinggi dalam kajian ini.

Jadual 2: Min dan Tahap Aplikasi Kemahiran Belajar dan Inovasi (4Cs)

\begin{tabular}{lllll}
\hline Konstruk & $\boldsymbol{N}$ & Min $(\boldsymbol{M})$ & Sisihan Piawai $(\boldsymbol{S D})$ & Tahap \\
\hline Kemahiran $4 C s$ & 60 & 3.79 & 0.19 & Sederhana Tinggi \\
Komunikasi & 60 & 3.82 & 0.20 & Sederhana Tinggi \\
Pemikiran kritis & 60 & 3.73 & 0.20 & Sederhana Tinggi \\
Kreativiti & 60 & 3.75 & 0.32 & Sederhana Tinggi \\
Kolaborasi & 60 & 3.84 & 0.21 & Sederhana Tinggi \\
\hline
\end{tabular}

\section{Tahap Aplikasi Kemahiran Komunikasi}

Berdasarkan Jadual 2, tahap aplikasi kemahiran komunikasi $(M=3.82, S D=0.20)$ berada pada tahap sederhana tinggi. Maka, dapat dirumuskan bahawa tahap aplikasi kemahiran komunikasi dalam kalangan murid sejarah berada pada tahap sederhana tinggi dalam kajian ini.

\section{Tahap Aplikasi Kemahiran Pemikiran Kritis}

Berdasarkan Jadual 2, tahap aplikasi kemahiran pemikiran kritis $(M=3.73, S D=0.20)$ berada pada tahap sederhana tinggi. Maka, dapat dirumuskan bahawa tahap aplikasi kemahiran pemikiran kritis dalam kalangan murid sejarah berada pada tahap sederhana tinggi dalam kajian ini.

\section{Tahap Aplikasi Kemahiran Kreativiti}

Berdasarkan Jadual 2, tahap aplikasi kemahiran kreativiti $(M=3.75, S D=0.32)$ berada pada tahap sederhana tinggi. Maka, dapat dirumuskan bahawa tahap aplikasi kemahiran kreativiti dalam kalangan murid sejarah berada pada tahap sederhana tinggi dalam kajian ini. 


\section{Tahap Aplikasi Kemahiran Kolaborasi}

Berdasarkan Jadual 2, tahap aplikasi kemahiran kolaborasi $(M=3.84, S D=0.21)$ berada pada tahap sederhana tinggi. Maka, dapat dirumuskan bahawa tahap aplikasi kemahiran kolaborasi dalam kalangan murid sejarah berada pada tahap sederhana tinggi dalam kajian ini.

\section{Tahap Aplikasi Kemahiran Belajar dan Inovasi (4Cs) Berdasarkan Jantina}

Berdasarkan Jadual 3, tahap aplikasi kemahiran belajar dan inovasi (4Cs) bagi murid lelaki dan murid perempuan berada pada tahap sederhana tinggi dalam kajian ini. Sungguhpun begitu, min aplikasi kemahiran $4 C s$ adalah lebih tinggi bagi murid lelaki $(M=3.81, S D=0.22)$ berbanding dengan murid perempuan $(M=3.77, S D=0.16)$. Maka, dapat dirumuskan bahawa tahap aplikasi kemahiran belajar dan inovasi (4Cs) dalam kalangan murid lelaki dan murid perempuan berada pada tahap sederhana tinggi dalam kajian ini.

Jadual 3: Min dan Tahap Aplikasi Kemahiran Belajar dan Inovasi (4Cs) berdasarkan Jantina

\begin{tabular}{|c|c|c|c|c|c|c|}
\hline \multirow[b]{2}{*}{ Konstruk } & \multicolumn{3}{|c|}{ Murid Lelaki $(N=29)$} & \multicolumn{3}{|c|}{ Murid perempuan $(N=31)$} \\
\hline & $\begin{array}{l}\text { Min } \\
(M)\end{array}$ & $\begin{array}{l}\text { Sisihan } \\
\text { Piawai } \\
\text { (SD) }\end{array}$ & Tahap & $\operatorname{Min}(M)$ & $\begin{array}{l}\text { Sisihan } \\
\text { Piawai } \\
\text { (SD) }\end{array}$ & Tahap \\
\hline Kemahiran $4 C s$ & 3.81 & 0.22 & $\begin{array}{l}\text { Sederhana } \\
\text { tinggi }\end{array}$ & 3.77 & 0.16 & $\begin{array}{l}\text { Sederhana } \\
\text { tinggi }\end{array}$ \\
\hline (a) Komunikasi & 3.81 & 0.22 & $\begin{array}{l}\text { Sederhana } \\
\text { tinggi }\end{array}$ & 3.82 & 0.18 & $\begin{array}{l}\text { Sederhana } \\
\text { tinggi }\end{array}$ \\
\hline $\begin{array}{l}\text { (b) Pemikiran } \\
\text { kritis }\end{array}$ & 3.76 & 0.21 & $\begin{array}{l}\text { Sederhana } \\
\text { tinggi }\end{array}$ & 3.70 & 0.18 & $\begin{array}{l}\text { Sederhana } \\
\text { tinggi }\end{array}$ \\
\hline (c) Kreativiti & 3.76 & 0.33 & $\begin{array}{l}\text { Sederhana } \\
\text { tinggi }\end{array}$ & 3.74 & 0.32 & $\begin{array}{l}\text { Sederhana } \\
\text { tinggi }\end{array}$ \\
\hline (d) Kolaborasi & 3.89 & 0.23 & $\begin{array}{l}\text { Sederhana } \\
\text { tinggi }\end{array}$ & 3.80 & 0.18 & $\begin{array}{l}\text { Sederhana } \\
\text { tinggi }\end{array}$ \\
\hline
\end{tabular}

\section{Tahap Aplikasi Kemahiran Komunikasi}

Berdasarkan Jadual 3, tahap aplikasi kemahiran komunikasi bagi murid lelaki dan murid perempuan berada pada tahap sederhana tinggi dalam kajian ini. Sungguhpun begitu, min aplikasi kemahiran komunikasi adalah lebih tinggi bagi murid lelaki $(M=3.81, S D=0.22)$ berbanding dengan murid perempuan $(M=3.82, S D=0.18)$. Maka, dapat dirumuskan bahawa tahap aplikasi kemahiran komunikasi dalam kalangan murid lelaki dan murid perempuan berada pada tahap sederhana tinggi dalam kajian ini.

\section{Tahap Aplikasi Kemahiran Pemikiran Kritis}

Berdasarkan Jadual 3, tahap aplikasi kemahiran pemikiran kritis bagi murid lelaki dan murid perempuan berada pada tahap sederhana tinggi dalam kajian ini. Sungguhpun begitu, min aplikasi kemahiran pemikiran kritis adalah lebih tinggi bagi murid lelaki $(M=3.76, S D=0.21)$ berbanding dengan murid perempuan $(M=3.70, S D=0.18)$. Maka, dapat dirumuskan bahawa tahap aplikasi kemahiran pemikiran kritis dalam kalangan murid lelaki dan murid perempuan berada pada tahap sederhana tinggi dalam kajian ini.

\section{Tahap Aplikasi Kemahiran Kreativiti}

Berdasarkan Jadual 3, tahap aplikasi kemahiran kreativiti bagi murid lelaki dan murid perempuan berada pada tahap sederhana tinggi dalam kajian ini. Sungguhpun begitu, min aplikasi kemahiran kreativiti adalah lebih tinggi bagi murid lelaki $(M=3.76, S D=0.33)$ berbanding dengan murid 
DOI: https://doi.org/10.47405/mjssh.v5i6.654

perempuan $(M=3.74, S D=0.32)$. Maka, dapat dirumuskan bahawa tahap aplikasi kemahiran kreativiti dalam kalangan murid lelaki dan murid perempuan berada pada tahap sederhana tinggi dalam kajian ini.

\section{Tahap Aplikasi Kemahiran Kolaborasi}

Berdasarkan Jadual 3, tahap aplikasi kemahiran kolaborasi bagi murid lelaki dan murid perempuan berada pada tahap sederhana tinggi dalam kajian ini. Sungguhpun begitu, min aplikasi kemahiran kreativiti adalah lebih tinggi bagi murid lelaki $(M=3.89, S D=0.23)$ berbanding dengan murid perempuan $(M=3.80, S D=0.18)$. Maka, dapat dirumuskan bahawa tahap aplikasi kemahiran kolaborasi dalam kalangan murid lelaki dan murid perempuan berada pada tahap sederhana tinggi dalam kajian ini.

\section{Perbezaan Min bagi Aplikasi Kemahiran Belajar dan Inovasi (4Cs) Berdasarkan Jantina}

Berdasarkan keputusan ujian Levene's yang tidak signifikan [ $F=1.20, p=0.28]$ pada Jadual 4 telah menunjukkan bahawa tidak terdapat perbezaan min yang signifikan bagi aplikasi kemahiran belajar dan inovasi $(4 C s)[t(58)=0.89, p=0.38]$ berdasarkan jantina. Maka, hipotesis nol $\left(\mathrm{H}_{\mathrm{ol}}\right)$ telah gagal ditolak. Justeru, dapat dirumuskan bahawa aplikasi kemahiran belajar dan inovasi (4Cs) adalah sama antara murid lelaki dan murid perempuan dalam kajian ini.

Jadual 4: Ujian-t Sampel Tak Bersandar Bagi Min Aplikasi Kemahiran Belajar dan Inovasi (4Cs) berdasarkan Jantina

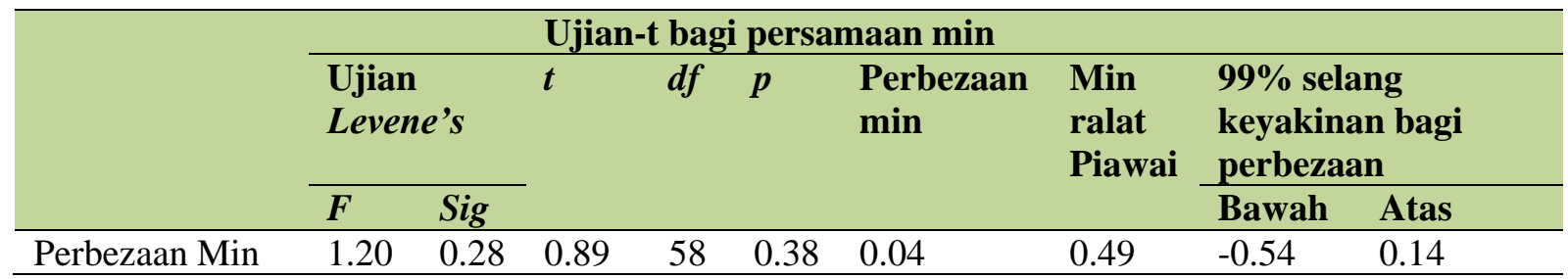

\section{Perbezaan Min bagi Aplikasi Kemahiran Komunikasi Berdasarkan Jantina}

Berdasarkan keputusan ujian Levene's yang tidak signifikan $[F=1.20, p=0.28]$ pada Jadual 5 telah menunjukkan bahawa tidak terdapat perbezaan min yang signifikan bagi aplikasi kemahiran komunikasi $[t(58)=-0.24, p=0.81]$ berdasarkan jantina. Maka, hipotesis nol $\left(\mathrm{H}_{\mathrm{ola}}\right)$ telah gagal ditolak. Justeru, dapat dirumuskan bahawa aplikasi kemahiran komunikasi adalah sama antara murid lelaki dan murid perempuan dalam kajian ini.

Jadual 5: Ujian-t Sampel Tak Bersandar Bagi Min Aplikasi Kemahiran Komunikasi berdasarkan Jantina

\begin{tabular}{|c|c|c|c|c|c|c|c|c|c|}
\hline & & & \multicolumn{7}{|c|}{ Ujian-t bagi persamaan min } \\
\hline & \multicolumn{2}{|c|}{$\begin{array}{l}\text { Ujian } \\
\text { Levene's }\end{array}$} & \multirow[t]{2}{*}{$t$} & \multirow[t]{2}{*}{$d f$} & \multirow[t]{2}{*}{$p$} & \multirow[t]{2}{*}{$\begin{array}{l}\text { Perbezaan } \\
\text { min }\end{array}$} & \multirow[t]{2}{*}{$\begin{array}{l}\text { Min } \\
\text { ralat } \\
\text { Piawai }\end{array}$} & \multicolumn{2}{|c|}{$\begin{array}{l}99 \% \text { selang } \\
\text { keyakinan bagi } \\
\text { perbezaan }\end{array}$} \\
\hline & $F$ & Sig & & & & & & Bawah & Atas \\
\hline Perbezaan Min & 1.06 & 0.31 & -0.24 & 58 & 0.81 & -0.01 & 0.05 & -0.12 & 0.09 \\
\hline
\end{tabular}




\section{Perbezaan Min bagi Aplikasi Kemahiran Pemikiran Kritis Berdasarkan Jantina}

Berdasarkan keputusan ujian Levene's yang tidak signifikan $[F=0.13, p=0.72]$ pada Jadual 6 telah menunjukkan bahawa tidak terdapat perbezaan min yang signifikan bagi aplikasi kemahiran pemikiran kritis $[t(58)=1.19, p=0.24]$ berdasarkan jantina. Maka, hipotesis nol $\left(\mathrm{H}_{\mathrm{olb}}\right)$ telah gagal ditolak. Justeru, dapat dirumuskan bahawa aplikasi kemahiran pemikiran kritis adalah sama antara murid lelaki dan murid perempuan dalam kajian ini.

Jadual 6: Ujian-t Sampel Tak Bersandar Bagi Min Aplikasi Kemahiran Pemikiran Kritis berdasarkan Jantina

\begin{tabular}{|c|c|c|c|c|c|c|c|c|c|}
\hline & \multicolumn{7}{|c|}{ Ujian-t bagi persamaan min } & \multirow{2}{*}{\multicolumn{2}{|c|}{$\begin{array}{l}99 \% \text { selang } \\
\text { keyakinan bagi } \\
\text { perbezaan }\end{array}$}} \\
\hline & \multicolumn{2}{|c|}{$\begin{array}{l}\text { Ujian } \\
\text { Levene's }\end{array}$} & \multirow[t]{2}{*}{$t$} & \multirow[t]{2}{*}{$d f$} & \multirow[t]{2}{*}{$p$} & \multirow[t]{2}{*}{$\begin{array}{l}\text { Perbezaan } \\
\text { min }\end{array}$} & \multirow[t]{2}{*}{$\begin{array}{l}\text { Min } \\
\text { ralat } \\
\text { Piawai }\end{array}$} & & \\
\hline & $F$ & Sig & & & & & & Bawah & Atas \\
\hline Perbezaan Min & 0.13 & 0.72 & 1.19 & 58 & 0.24 & 0.06 & 0.05 & -0.04 & 0.16 \\
\hline
\end{tabular}

\section{Perbezaan Min bagi Aplikasi Kemahiran Kreativiti Berdasarkan Jantina}

Berdasarkan keputusan ujian Levene's yang tidak signifikan $[F=0.08, p=0.79]$ pada Jadual 7 telah menunjukkan bahawa tidak terdapat perbezaan min yang signifikan bagi aplikasi kemahiran kreativiti $[t(58)=0.30, p=0.77]$ berdasarkan jantina. Maka, hipotesis nol $\left(\mathrm{H}_{\mathrm{olc}}\right)$ telah gagal ditolak. Justeru, dapat dirumuskan bahawa aplikasi kemahiran kreativiti adalah sama antara murid lelaki dan murid perempuan dalam kajian ini.

Jadual 7: Ujian-t Sampel Tak Bersandar Bagi Min Aplikasi Kemahiran Kreativiti berdasarkan Jantina

\begin{tabular}{|c|c|c|c|c|c|c|c|c|c|}
\hline \multicolumn{10}{|c|}{ Ujian-t bagi persamaan min } \\
\hline & \multicolumn{2}{|c|}{$\begin{array}{l}\text { Ujian } \\
\text { Levene's }\end{array}$} & \multirow[t]{2}{*}{$t$} & & \multirow[t]{2}{*}{$p$} & \multirow[t]{2}{*}{$\begin{array}{l}\text { Perbezaan } \\
\text { min }\end{array}$} & \multirow[t]{2}{*}{$\begin{array}{l}\text { Min } \\
\text { ralat } \\
\text { Piawai }\end{array}$} & \multicolumn{2}{|c|}{$\begin{array}{l}99 \% \text { selang } \\
\text { keyakinan bagi } \\
\text { perbezaan }\end{array}$} \\
\hline & $F$ & Sig & & & & & & Bawah & Atas \\
\hline Perbezaan Min & 0.08 & 0.79 & 0.30 & 58 & 0.77 & 0.03 & 0.08 & -0.14 & 0.19 \\
\hline
\end{tabular}

\section{Perbezaan Min bagi Aplikasi Kemahiran Kolaborasi Berdasarkan Jantina}

Berdasarkan keputusan ujian Levene's yang tidak signifikan $[F=0.36, p=0.55]$ pada Jadual 8 telah menunjukkan bahawa tidak terdapat perbezaan min yang signifikan bagi aplikasi kemahiran kolaborasi $[t(58)=1.67, p=0.10]$ berdasarkan jantina. Maka, hipotesis nol $\left(\mathrm{H}_{\mathrm{old}}\right)$ telah gagal ditolak. Justeru, dapat dirumuskan bahawa aplikasi kemahiran kolaborasi adalah sama antara murid lelaki dan murid perempuan dalam kajian ini.

Jadual 8: Ujian-t Sampel Tak Bersandar Bagi Min Aplikasi Kemahiran Kreativiti berdasarkan Jantina

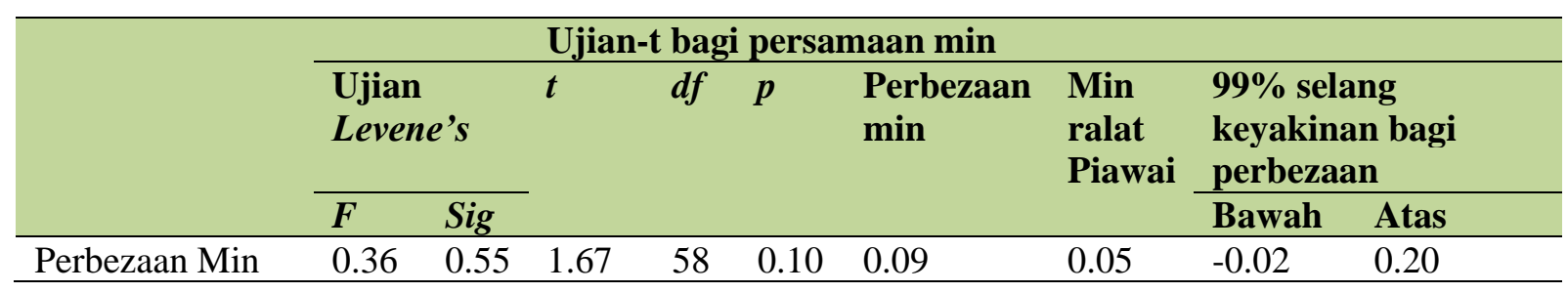




\section{Perbincangan Kajian}

Dapatan kajian ini yang menunjukkan bahawa tahap aplikasi kemahiran belajar dan inovasi (4Cs) iaitu kemahiran komunikasi, kemahiran pemikiran kritis, kemahiran kreativiti dan kemahiran kolaborasi yang berada pada tahap sederhana tinggi dalam kalangan murid adalah sealiran dengan dapatan kajian Zamri dan Nor Syazwani (2013) yang telah melaporkan bahawa tahap kemahiran generik seperti kemahiran berkomunikasi, kemahiran teknologi maklumat dan komunikasi, kemahiran kepimpinan, kemahiran kerja berpasukan dan kemahiran pemikiran kritis berada pada tahap sederhana dalam kalangan murid tingkatan empat yang mengambil mata pelajaran Kesusasteraan Melayu dan kajian Irwan, Mohd Mahzan dan Abd Razaq (2020) yang melaporkan bahawa tahap kemahiran insaniah iaitu kemahiran berfikir aras tinggi, kemahiran sosial-interpersonal, kemahiran memimpin dan kemahiran menyelesaikan masalah berada pada tahap sederhana tinggi dalam kalangan murid tingkatan empat dari Sekolah Menengah Kebangsaan, Sekolah Menengah Jenis Kebangsaan Cina, Sekolah Menengah Kebangsaan Agama dan Sekolah Berasrama Penuh. Tambahan pula, tahap kemahiran 4Cs iaitu kemahiran pemikiran kritis dan kreativiti yang berada pada tahap sederhana, manakala kemahiran kolaborasi dan kemahiran komunikasi yang berada pada tahap tinggi melalui pelaksanaan Environemental Change Learning Tools based STEM-PjBL seperti yang dilaporkan dalam kajian Dwita, Yustinus dan Saiful (2020) serta dapatan kajian Muhammad Sabri, Nurulhuda dan Ilyani (2020) juga telah melaporkan bahawa peratus dan kekerapan kemahiran 4Cs iaitu kemahiran kreativiti, kemahiran pemikiran kritis, kemahiran kolaborasi dan kemahiran komunikasi yang berada pada tahap tinggi dan sederhana dalam kalangan pelajar jurusan pengajian Sarjana Pendidikan Bahasa Arab sebagai bahasa kedua serta dapatan kajian YM Raja Abdulah Raja dan Daud (2018) yang juga telah melaporkan bahawa tahap pengetahuan terhadap amalan konsep 4C yang tinggi secara keseluruhannya walaupun tahap kemahiran kreativiti dan pemikiran kritis berada pada tahap sederhana, manakala kemahiran kolaborasi dan komunikasi berada pada tahap tinggi bagi pelajar-pelajar dalam pengajian Agama di Institut Pendidikan Guru Kampus Dato' Razali Ismail telah menyokong dapatan kajian ini secara langsung mahupun secara tidak langsung. Hal ini demikian kerana aplikasi kemahiran belajar dan inovasi (4Cs) menjadi teras kepada pembelajaran abad ke-21 dimana murid-murid berperanan aktif dalam proses pembelajaran dan pemudahcaraan yang dilaksanakan di dalam kelas, di samping membentuk kemenjadian murid-murid dari aspek pengetahuan, kemahiran dan perwatakan serta melahirkan murid-murid yang berupaya bersaing di peringkat global (PPK, 2018).

Tambahan pula, dapatan kajian ini yang menunjukkan bahawa tahap aplikasi kemahiran belajar dan inovasi (4Cs) iaitu kemahiran komunikasi, kemahiran pemikiran kritis, kemahiran kreativiti dan kemahiran kolaborasi yang berada pada tahap sederhana tinggi dalam kalangan murid lelaki dan perempuan walaupun tidak terdapat perbezaan min yang signifikan bagi aplikasi kemahiran belajar dan inovasi (4Cs) berdasarkan jantina adalah konsisten dengan dapatan kajian Mohd Sahrul \& Muhammad Suhaimi (2020) yang telah melaporkan bahawa tahap penggunaan media digital berada pada tahap sederhana dan tidak terdapat perbezaan min yang signifikan bagi penggunaan media digital antara murid lelaki dan murid perempuan, dapatan kajian Nurul Hashrah, Noor Hasimah dan Nur Aida (2015) yang telah melaporkan bahawa tidak terdapat perbezaan yang signifikan bagi penguasaan kemahiran abad ke-21 dalam mata pelajaran matematik berdasarkan jantina dan dapatan kajian Huang dan Zanaton (2019) yang telah melaporkan bahawa tidak terdapat perbezaan signifikan dalam tahap kefahaman guru terhadap pembelajaran abad ke-21 berdasarkan jantina. Tambahan pula, dapatan kajian Balan dan Ivy (2014) yang telah melaporkan bahawa tidak terdapat perbezaan dalam pembelajaran kreativiti berdasarkan jantina dan dapatan kajian Noorul Jannah dan Nur Aishah (2019) yang turut telah melaporkan bahawa tidak terdapat perbezaan kemahiran abad ke-21 dalam mata pelajaran perniagaan berdasarkan jantina dan lokasi sekolah telah menyokong dapatan kajian ini. Justeru, dapat dirumuskan bahawa aplikasi kemahiran belajar dan inovasi (4Cs) adalah sama dalam kalangan murid lelaki mahupun dalam kalangan murid perempuan dalam kajian ini.

\section{Kesimpulan}

Kesimpulannya, tahap aplikasi kemahiran belajar dan inovasi (4Cs) iaitu kemahiran komunikasi, kemahiran pemikiran kritis, kemahiran kreativiti, kemahiran kolaborasi berada pada tahap sederhana 
tinggi dalam kalangan murid sejarah. Justeru, guru-guru perlu memberi penekanan dalam pemupukan aplikasi kemahiran belajar dan inovasi (4Cs) yang lebih baik dalam kalangan murid melalui pelaksanaan pedagogi Abad ke-21 dan seiring dengan trend perkembangan teknologi maklumat dan komunikasi yang terus berkembang pesat dalam era globalisasi ini.

\section{Rujukan}

Balan, K \& Ivy, L. (2014). Pembelajaran kreativiti berdasarkan jantina pelajar tingkatan empat di Kota Kinabalu Sabah. Seminar Kebangsaan Integriti Keluarga, 1-6.

Dwita, T., Yustinus, V.A \& Saiful, R. (2020). Effectiveness of environmental change learning tools based STEM-PjBL towards 4C skills of students. Journal of Innovative Science Education, 9(2), 181-187.

Irwan Fariza Sidik, Mohd Mahzan Awang \& Abd Razaq Ahmad. (2020). Keterlibatan Pelajar dan hubungannya dengan kemahiran insaniah. Jurnal Pendidikan Malaysia, 45(1), 68-74.

Irwan Fariza Sidik, Mohd Mahzan Awang \& Abdul razaq Ahmad. (2019). Teacher's support and student involvement in learning activities on enhancing student academic achievement. The Journal of Social Sciences Research, 5(7), 1167-1175.

Kaviza, M. (2020). Amalan Kemahiran Pembelajaran Terarah Kendiri dalam Mata pelajaran Sejarah: Perspektif murid Tingkatan dua. Malaysian Journal of Social Sciences \& Humanities, 5(1), 109115.

Kementerian Pendidikan Malaysia. (2013). Pelan Pembangunan Pendidikan Malaysia 2013-2025. Putrajaya: Kementerian Pendidikan Malaysia.

Mohd Sahrul Nizam Sahidin \& Muhammad Suhaimi Taat. (2020). Pembelajaran koperatif kemahiran 4K dan penggunaan media digital terhadap sikap akademik pelajar. Malaysian Journal of Social Sciences and Humanities, 5(4), 133-141.

Muhammad Ayisy Baharudin \& Mohd Ashraf Ibrahim. (2019). Kesediaan pelaksanaan pengajaran abad ke-21 dalam kalangan guru pelatih sejarah IPG Zon Selatan. Jurnal Penyelidikan Sains Sosial, 2(5), 32-42.

Muhammad Sabri Shahrir, Nurulhuda Osman \& Ilyani Syiham Muhammad. (2020). Aplikasi Konsep 4C pembelajaran abad ke-21 dalam kalangan guru pelajar sarjana mod pengajian pendidikan bahasa Arab cuti sekolah UIAM. e-Jurnal Bahasa dan Linguistik, 2(1), 12-22.

Noorul Jannah Azaman \& Nor Aishah Buang (2019). Tahap kemahiran abad ke-21 pelajar dalam mata pelajaran perniagaan berdasarkan lokasi sekolah dan jantina. International Conference in Global Education VII, 851-858.

Nunnally, J.C. (1978). Psychometrie Theory (2 $2^{\text {nd }}$ ed.). New York: McGraw Hill.

Nurazuraini Mustapa, Mahzan Awang \& Abdul Razaq Ahmad (2016). 21 $1^{\text {st }}$ Century knowledge and skills in teaching and learning history. International Conference on Education and Regional development, 10-17.

Nurul Hashrah Salehudin, Noor Hasimah Hassan, Nur Aida Abd Hamid. (2015). Matematik dan Kemahiran abad ke-21: Perspektif pelajar. Jurnal Pendidikan Matematik, 3(1), 24-36.

Partnership for 21st Century Skills. (2006). Framework for 21st century learning. Retrieved from http://www.p21.org/documents/ProfDev.pdf

Pusat Perkembangan Kurikulum. (2018). Dokumen Standard Kurikulum dan Pentaksiran Sejarah Tingkatan 4 dan 5. Putrajaya: Kementerian Pendidikan Malaysia.

Rohani Arbaa, Hazri jamil \& Mohammad Zohir Ahmad. (2017). Model Bersepadu Penerapan Kemahiran Abad ke-21 dalam Pengajaran dan Pembelajaran, Jurnal Pendidikan Malaysia, 42(1), $1-11$.

Said Hamid Hasan. (2019). Pendidikan Sejarah untuk kehidupan abad ke-21. HISTORIA: Jurnal Pendidik dan Peneliti Sejarah, 2(2), 61- 72.

YM Raja Abdullah Raja Ismail \& Daud Ismail. (2018). Aplikasi 'Konsep 4C' pembelajaran abad ke21 dalam kalangan guru pelatih pengajian agama Institut pendidikan guru kampus Dato' Razali Ismail. Asian People Journal, 1(1), 45-65.

Zamri Mohamad \& Noor Syazwani Rani (2013). Tahap kemahiran generik pelajar dalam pembelajaran kesusasteraan melayu. Sains Humanika, 64(1), 17-21. 